\title{
FARMACIJOS SPECIALISTU KONSULTACIJU TURINYS IŠDUODANT RECEPTINIUS VAISTUS: SKIRTUMAI TARP LYČIŲ IR AMŽIAUS GRUPIŲ
}

\author{
Jurgita Daukšiene் $\dot{1}^{1,2}$, Laimutė Jonaitiené2 $\dot{2}^{2}$ Edita Kizevičiené ${ }^{2}$ \\ ${ }^{1}$ Lietuvos sveikatos mokslu universiteto Medicinos akademijos Farmacijos fakultetas, \\ ${ }^{2}$ Kauno kolegija, Medicinos fakultetas
}

Raktažodžiai: farmacijos specialistai, farmacinè paslauga, konsultavimas, receptiniai vaistai.

\section{Santrauka}

Tiksli, teisinga ir nevėluojanti informacija apie vaistus ir sveikatos stiprinimą yra svarbus sveikatos priežiūros ir saugaus vaistų vartojimo komponentas. Šiandien pacientams prieinama daug rašytinių, vaizdinių ir interaktyvių informacijos šaltinių. Dalis pacientus pasiekiančios informacijos gali būti dviprasmiška ar netgi klaidinanti. Tyrimai rodo, kad tinkama informacija apie vaistus svarbi ne tik nereceptinių, bet ir receptinių vaistų ịsigijimo metu. Darbo tikslas buvo atskleisti farmacijos specialistų vaidmenį išduodant nereceptinius vaistinius preparatus visuomenès vaistinèje. Pasirinktas struktūrizuotas stebejjimo tyrimas. Išanalizuota daugiau kaip 4000 teikiamų visuomenès vaistinèse konsultacijų turinys. Rezultatai: iš stebètų 4198 farmacijos specialistų konsultacijų, 1331 atvejais gyventojas įsigijo tik receptinius vaistus. Trečdalis visų vaistinès pacientų apsipirkimo vaistinejje metu įsigijo receptinius vaistinius preparatus, daugiau negu pusė pirko receptinius kompensuojamus vaistus $(65,8 \%)$, likusi dalis - nekompensuojamus $(34,2 \%)$. Didžiausia respondentų dalis receptinius vaistinius preparatus pirko pagal 3 formos recepto blankus (63,6 \%). Farmacijos specialistai, išduodami receptinius vaistinius preparatus, suteikè minimalią informaciją apie vaistą. Vidutiniškai vieno vizito metu buvo aptariama 1,62 vaisto vartojimo aspekto. Dažniausiai suteikiama informacija apie vaistą buvo: kaip vartoti, kada vartoti ir kaip ilgai vartoti išrašytą receptinị vaistinį preparatą. Daugeliu atvejų informacija suteikiama žodžiu ir raštu, ir vidutiniškai skiriant 4,04 minutès laiko vienam pacientui.
Ivadas

A. Kamekis ir kt. nuomone, tiksli, teisinga ir laiku suteikta informacija apie vaistus ir sveikatos stiprinimą yra svarbus sveikatos priežiūros ir saugaus vaistų vartojimo komponentas [1]. Vaistai - ypatinga prekè. Juos vartojant ne pagal paskirtį ar nepaisant tinkamo vaistų vartojimo nuorodų, galima ne tik nepasiekti norimų tikslų (išgyti, stabilizuoti būklę, sumažinti ligos progresavimą ar pagerinti gyvenimo kokybę), bet pabloginti esamą paciento sveikatos būklę. K. Hämeen-Anttila ir kt. parodo, kad šiandien pacientams yra prieinama daug rašytinių, vaizdinių ir interaktyvių informacijos šaltinių. Dalis pacientus pasiekiančios informacijos gali būti dviprasmiška ar netgi klaidinanti [2]. Itin svarbu, kad, prieš priimdami reikšmingus gydymosi sprendimus, pacientai konsultuotųsi su atitinkamą išsilavinimą turinčiu sveikatos priežiūros specialistu - gydytoju, vaistininku ar slaugytoju. Ivairiose šalyse atlikti tyrimai liudija, jog vaistininkai - lengviausiai pasiekiami sveikatos priežiūros specialistai $[3,4]$.

Pagal Lietuvos Respublikos Farmacijos ịstatymą Nr. X-709 „Farmaciné paslauga - farmacijos specialisto praktika vaistinëje, apimanti gydytojo išrašytų receptų kontrolę, vertinimą, nereceptinių vaistinių preparatų parinkimą, farmacinès informacijos apie vaistinius preparatus teikimą gyventojams, sveikatos priežiūros ir farmacijos specialistams, taip pat jų konsultavimą“" [5]. Farmacinè paslauga vaistinejje teikiama vadovaujantis LR sveikatos apsaugos ministro įsakymu patvirtintomis „Geros vaistinių praktikos nuostatomis“ [6]. E. C. Tan ir kt. pabrežia, kad farmacinès paslaugos teikimas negalimas be tiesioginio paciento ir farmacijos specialisto dalyvavimo [7]. J. Schommer ir kt. tyrimai rodo, kad tinkama informacija apie vaistus svarbi ne tik nereceptinių, bet ir receptinių vaistų ịsigijimo metu [8]. Suteikiant tinkamą farmacinę paslaugą, farmacijos specialistas turi kuo paprasčiau ir suprantamais žodžiais pateikti pacientui visą būtiną ir tikslią informaciją apie vaistinio preparato vartojimo ypa- 
tumus, saugumą, gydomaji efektą ir galimą nepageidaujamą poveikį. E. S. Koster ir kt. [9], J. Daukšienè [10] teigia, kad tinkamai suteikta farmacinè paslauga gali pagerinti paciento vartojamų vaistų efektą. Tinkamai informuotas apie jam paskirtus vaistus asmuo išvengia gydymosi klaidų: neįsigyja nebūtinų vaistų, nevartoja vaistų per didelèmis ar suboptimaliomis dozėmis, paiso optimalios gydymo trukmès ir taip išvengia nepageidaujamo vaistų poveikio. $\mathrm{F}$. Boeni ir kt. tyrimai rodo, kad konsultavimas turètu apimti informaciją apie vaisto pavadinimą ir paskirti, naudojimo instrukcijas, šalutinị poveiki, atsargumo priemones, kontraindikacijas ir saugojimą bei dèl vaistų sąveikos ir nepageidaujamų vaistų reakcijų stebėseną [11]. F. W. K. Chan ir kt. tyrimo rezultatai atskleidžia, kad pacientai, sergantys lètinèmis ligomis, dažnai keičia vaistų vartojimo režimą, norẻdami išvengti vartojamo vaisto šalutinių poveikių ir išlaikyti jų gyvenimo kokybę [12].

Tyrimo tikslas - atskleisti farmacijos specialistu vaidmenị išduodant receptinius vaistinius preparatus visuomenès vaistinèje.

\section{Tyrimo objektas ir metodika}

Tyrimo objektas - farmacijos specialistų vaidmens, išduodant receptinius vaistus, elementų analizè.

Atliekant tyrimą, taikyti metodai: mokslo šaltinių analizè, aprašomojo tyrimo stebejjimo metodas. Tyrimo metu 26 Lietuvos vaistinèse, gavus farmacijos specialistų leidimą, buvo stebimas jų darbas, parduodant vaistinius preparatus, vaistinių prekes ir teikiant rekomendacijas gyventojams. Statistinè duomenų analizė atlikta naudojant SPSS 17.0 ir Microsoft Office programinę irangą.

Tyrimo dalyviai - tyrime dalyvavusiose visuomenès vaistinėse dirbantys farmacijos specialistai ir atsitiktinai atrinkti gyventojai, besilankantys šiose vaistinèse. Tyrimas buvo atliekamas nuo 2016 m. gegužès 24 dienos iki 2016 $\mathrm{m}$. liepos 06 dienos.

1 lentelè. Sociodemografiniai tiriamujų duomenys $(N=4198)$.

\begin{tabular}{|c|c|c|c|c|c|}
\hline \multicolumn{2}{|c|}{$\begin{array}{l}\text { Analizuojami pa- } \\
\text { cientų požymiai }\end{array}$} & \multicolumn{2}{|c|}{ Bendri tiriamieji } & \multicolumn{2}{|c|}{$\begin{array}{c}\text { Tiriamieji, ịsigiję } \\
\text { tik receptinị vais- } \\
\text { tinị preparatą }\end{array}$} \\
\hline & & $\begin{array}{l}\text { Skaičius } \\
(\mathrm{N})\end{array}$ & $\begin{array}{c}\text { Procentai } \\
\text { (proc.) }\end{array}$ & $\begin{array}{l}\text { Skaičius } \\
(\mathrm{N})\end{array}$ & $\begin{array}{c}\text { Procentai } \\
\text { (proc.) }\end{array}$ \\
\hline \multirow{2}{*}{ Lytis } & Moteris & 2754 & 65,6 & 871 & 65,3 \\
\hline & Vyras & 1443 & 34,4 & 460 & 34,6 \\
\hline \multicolumn{2}{|l|}{ Iš viso } & 4198 & 100 & 1331 & 100 \\
\hline \multirow{3}{*}{ Amžius } & $18-30$ & 927 & 22,1 & 151 & 11,4 \\
\hline & $30-55$ & 1849 & 44,0 & 591 & 44,3 \\
\hline & $55<$ & 1401 & 33,4 & 589 & 44,3 \\
\hline \multicolumn{2}{|l|}{ Iš viso } & 4198 & 100 & 1331 & 100 \\
\hline
\end{tabular}

Tyrimo instrumentas, tiriamųjų kontingentas. Tyrimui atlikti pasirinktas stebejjimo metodas, kuris, pagal $\mathrm{J}$. Creswell, padeda tyrejui surinkti duomenis apie individualy asmenų elgesị ir veiklas tyrimo lauke [13]. Remiantis K. Kardelio [14] stebejjimo metodo aprašymais, galima teigti, kad šis stebejjimo tyrimas nepriklausè nuo tiriamojo nuostatų, noro atsakinèti i pateiktus klausimus. Tiriamojo veiksmus ir elgesị galima tiksliau įvertinti jị stebint, nei apklausiant pati tiriamajị. Stebejimo metu fiksuojami tiriamujų elgesio kategorijų duomenys buvo žymimi stebejjimo lentelèse. Iš viso buvo užpildyta 4198 stebèjimo lentelių, iš kurių atrinkta 1331 atvejis, kai buvo pirkti receptiniai vaistiniai preparatai ir kitos vaistinių prekès.

Stebejimo lentelių kategorijos skirstytos ị šias dalis: 1) demografiniai duomenys, 2) receptinių vaistų receptų formų pasiskirstymas tarp tiriamujjų, 3) ịsigyjamų vaistų kiekis, 4) laikas, per kuri farmacijos specialistas suteikè informaciją pacientui, 4) farmacijos specialisto suteiktos informacijos pacientui turinys, 5) farmacijos specialisto informacijos pacientui suteikimo būdai.

Tyrimo metu vaistinèse atsitiktinai stebèta 4198 vaistinių preparatų ar vaistinių prekių pirkimai, kurių metu farmacijos specialistas konsultavo pacientą. Analizuojant bendrus duomenis, pastebèta, kad didžiają pacientų dalị sudarè moterys $(65,6 \%)$, receptinius vaistinius preparatus įsigijo du kartus daugiau moterų negu vyrų. Analizuojant duomenis pagal amžių, pastebèta, kad vaistinèje daugiausia lankèsi vidutinio $(44,0 \%)$ arba vyresnio amžiaus gyventojai (43,0 \%), receptinius vaistinius preparatus daugiausia pirko 30-55 metu asmenys (44,3\%) (1 lentelè).

\section{Rezultatų aptarimas}

Vaistiniai preparatai receptiniams vaistiniams preparatams priskiriami vaistų registracijos metu ne atsitiktinai, o rūpinantis žmonių sveikata, saugant juos nuo perdozavimo, netinkamo vaistų vartojimo ir galimų neigiamų pasekmių. Farmacijos specialisto suteikiama informacija, išduodant receptinius vaistinius preparatus, padeda išvengti gydymosi vaistais klaidų. Tyrimo metu siekta išsiaiškinti, kokius receptinius vaistinius preparatus pacientai dažniausiai perka, ir kokia pateikiama recepto blanko forma. Tyrimo rezultatu analizè parodè, kad trečdalis visų vaistinés pacientų apsipirkimo vaistinejje metu ịsigijo receptinius vaistinius preparatus, kurių daugiau negu puse - receptiniai kompensuojamieji vaistai $(65,8 \%)$, likusi dalis - nekompensuojamieji $(34,2 \%)$.

Nagrinejjant receptų formų pasiskirstymą tarp tiriamujų, paaiškejjo, kad 28,7 \% tiriamujų pirko receptinius vaistus pagal 1 formos recepto blankus, mažiausia dalis jų įsigijo vaistus pagal specialius 2 formos recepto blankus $(4,2 \%)$, didžiausia dalis - receptinius vaistinius preparatus pirko 
pagal 3 formos recepto blankus (63,6\%). Pastebèta, kad išimtinais atvejais pacientai įsigijo receptinius vaistus neturèdami recepto $(2,2 \%)$, maža jų dalis - pateikdami kelis 1 ir 2 ar 3 formų receptus (1,3\%).

R. J. Holden ir kt. [15], H. P. Puspitasari ir kt. [16] atskleidžia, kad kompensuojamieji receptiniai vaistiniai preparatai išrašomi gydytojo pacientams, dažniausiai sergantiems lètinèmis ligomis, kai nejaučiama skausmo, vaistai vartojami ilgą laiką, esant psichologinèms problemoms, baimèms dèl vartojamų ilgą laikotarpị vaistų neigiamo poveikio organizmui ar kai kurių organų būklei. Visa tai gali turèti įtakos netinkamam vaistų vartojimui. A. Kamekis ir kt. [1], M. S. Murad ir kt. [17] nuomone, išduodant vaistini preparatą, farmacijos specialistas gali aktyvinti pacientą vartoti vaistą pagal gydytojo nurodymus, priminti jam vaistų vartojimo ypatumus, vartojimo režimą.

Pacientui tai ypač svarbu, kai jis ịsigyja vieno vizito metu ne vieną vaistą.

Gauti mūsų tyrimo duomenys parodė tinkamos farmacinès paslaugos poreikị, nes ịsigytų vaistinèje vieno apsipirkimo metu kompensuojamųjų vaistinių preparatų kiekio vidurkis yra - 1,74 ir nekompensuojamųjų receptinių vaistinių preparatų kiekio vidurkis - 1,24.

Tyrimo metu tirta, kiek receptinių vaistinių preparatų pa-

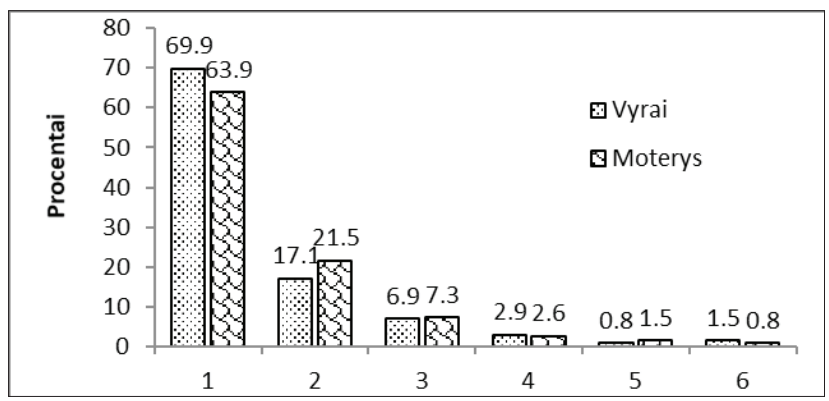

1 pav. Vieno vizito metu paciento įsigytų vaistinèje receptinių vaistinių preparatų kiekis $(\mathrm{N}=1331)$.

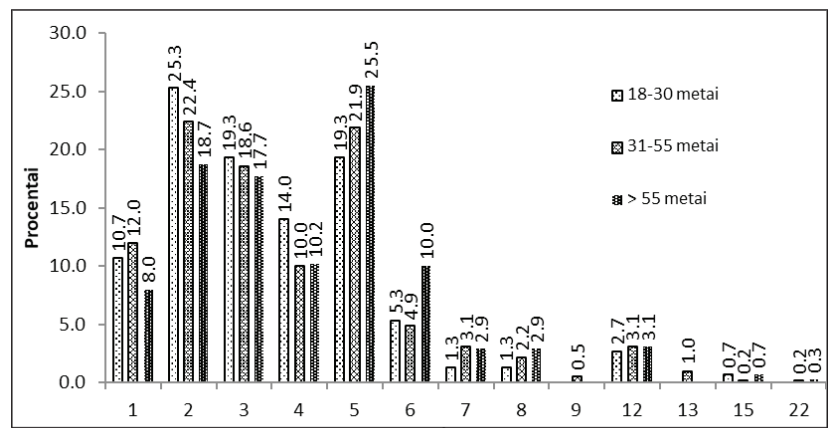

2 pav. Farmacijos specialisto suteikiamos konsultacijos ịvairaus amžiaus pacientams trukmè $(\mathrm{N}=1331)$. cientas perka vienu metu. Išduodamų receptinių vaistų kiekis atsispindi 1 paveiksle. Iš gautų tyrimo duomenų išryškejjo, kad vieno apsipirkimo metu pacientai ịsigijo dažniausiai vieną receptinį vaistinị preparatą (66,0 \% respondentų). İsigytų vaistinių preparatų kiekis beveik nepriklausè nuo tiriamujų lyties. Tai patvirtino ir ištirta įsigytų receptinių vaistinių preparatų vidutinio kiekio priklausomybè nuo tiriamujų lyties (2 lentelè). Taip pat išryškèjo, kad kuo pacientai vyresnio amžiaus, tuo daugiau vaistinių preparatų jie issigijo, tuo labiau turetų diferencijuotis suteikiamos farmacinès paslaugos trukmé, turinys.

Tyrimo duomenu analizè parodè, kad farmacijos specialisto konsultacija truko vidutiniškai 4,04 minutès (moda -5). Ketvirtadaliui jauniausių respondentų grupèms - (1830 metu grupè) ir vidutinio amžiaus (31 - 55 metų grupè) farmacijos specialisto suteikiama informacija apie vaistą truko 2 minutes ( moda -2). Penktadaliui vyresnio amžiaus

2 lentelè. İsigyjamų receptinių vaistinių preparatų vidutinio kiekio priklausomybė nuo paciento amžiaus ir lyties $(\mathrm{N}=1331)$.

\begin{tabular}{|l|c|c|}
\hline \multicolumn{2}{|l|}{ Požymis } & $\begin{array}{c}\text { Vidutinis ịsigyjamų receptinių vais- } \\
\text { tinių preparatų kiekis }\end{array}$ \\
\hline \multirow{2}{*}{ Lytis } & Moterys & 1,67 \\
\cline { 2 - 3 } & Vyrai & 1,49 \\
\hline \multirow{2}{*}{$\begin{array}{l}\text { Amžiaus } \\
\text { grupe }\end{array}$} & $18-30$ & 1,39 \\
\cline { 2 - 3 } & $30-55$ & 1,57 \\
\cline { 2 - 3 } & $<55$ & 1,72 \\
\hline
\end{tabular}

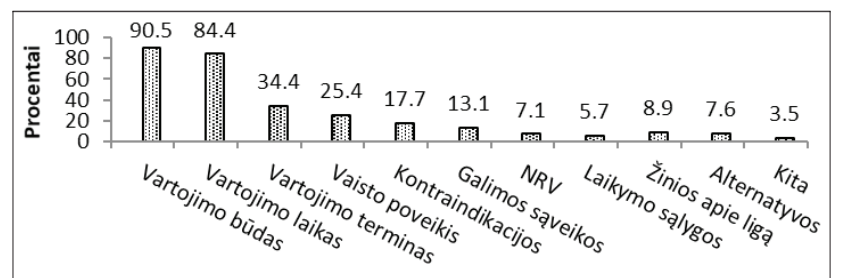

3 pav. Farmacijos specialisto vaistineje suteikiamos pacientui farmacinès konsultacijos turinys $(\mathrm{N}=1331)$.

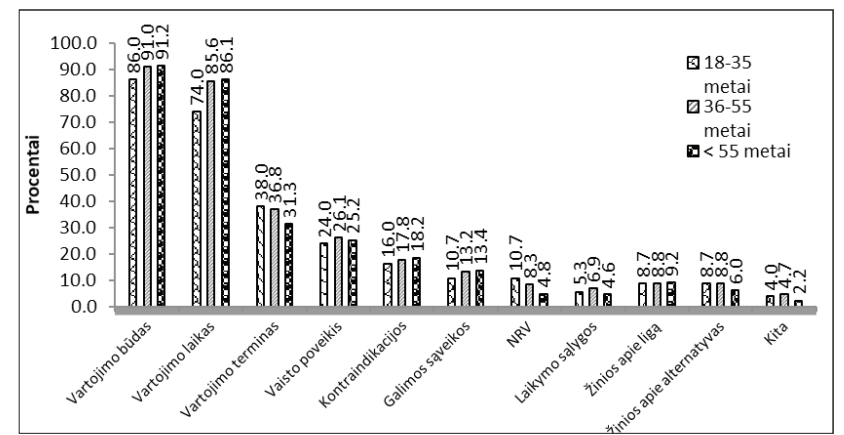

4 pav. Farmacijos specialisto vaistinèje suteikiamos farmacinès konsultacijos turinys ịvairaus amžiaus pacientams $(\mathrm{N}=1331)$. 


\section{4}

respondentų farmacinè paslauga truko 5 minutes ( moda -5). Pastebint, kad vyresnio amžiaus respondentai ịsigijo didesnị kiekị vaistų, galima teigti, kad farmaciné paslauga buvo teikiama profesionaliai, informuojant apie kiekvieno vaisto vartojimą ( 2 pav.).

E. S. Koster ir kt. [9] pažymi, kad į vaistinę atėjęs žmogus tikisi ne tik ịsigyti vaistą, bet ir gauti visą informaciją apie jị. Šiuo tyrimu siekta, stebint konsultaciją, išsiaiškinti, kokią informaciją suteikia farmacijos specialistas konsultacijos metu. Iš gautų rezultatų matome, kad dažniausiai farmacijos specialistas suteikè informaciją: kaip receptini vaistinị preparatą vartoti $(90,5 \%)$, kada ji vartoti $(84,4 \%)$ ir kaip ilgai vartoti (34,4\%). Pastebèta, kad konsultacijos metu rečiau buvo suteikiama žinių apie vaistą: koks vaisto poveikis, kontraindikacijas, galima vaistų sąveika, nepageidaujamos reakcijos ị vaistą (NRV). Mažiausiai informacijos buvo suteikta apie pačią ligą, alternatyvas, vaistų laikymo sąlygas (nuo 8,9 \% iki 5,7 \%) (3 pav.).

Tyrimas parodè, kad trečdalis farmacijos specialistų, suteikdami farmacinę paslaugą, informaciją teikè žodžiu $(34,7$ \%), daugiau kaip du trečdaliai pacientus informavo žodžiu ir raštu $(58,0 \%$ \%), farmacijos specialistai raštu informaciją teikè labai retai $(4,7 \%)$. Labai retai $(4,7 \%)$ farmacinè konsultacija nebuvo suteikta.

K. Svensberg ir kt. teigia, kad veiksmingas vaistininko ir paciento bendravimas turétų būti skirtas vaistų vartojimo problemos nustatymui, įsitikinant, kad pacientai kiekvienu atveju vartoja saugų ir veiksmingą vaistą, plèsti pacientų žinias apie vaistus ir paciento ligą, ittikinti pacientą priimti pagrisstus sprendimus vartojant vaistus, bendradarbiaujant su gydytoju gerinti savo gyvenimo būdą [18].

J. J. Mira ir kt. [19] tyrimu parodo, kad senyvi, sergantys lètinèmis ligomis pacientai nežino atsargumo priemonių, padedančių saugiai vartoti vaistus. Kai gydytojai pakeičia receptus, keičia dozes ar priskiria naujus vaistus, tuomet vaistinès pacientą reikia plačiau informuoti apie saugų vaistu vartojimą, ir tuo farmacinès paslaugos suteikimo metu prisidèti prie gydymo klaidų mažinimo.

Mūsų tyrimo duomenų analizè parodè, kad pacientų amžius turejjo įtakos informacijos suteikimui apie vaistini preparatą. 36 - 55 metų ir vyresni nei 55 metai pacientai dažniausiai gavo informaciją apie vaistą: kaip vartoti ( 91\%), kada vartoti ( $\sim 86 \%)$, kontraindikacijos ( $\sim 18 \%)$. 18 - 30 metų amžiaus tiriamujų grupei informacijos apie vaistą buvo suteikta mažiausiai (4 pav.).

\section{Išvados}

1. Trečdalis visų vaistinès pacientų apsipirkimo vaistinèje metu įsigyja receptinius vaistinius preparatus, daugiau negu pusè perka receptinius kompensuojamus vaistus $(65,8$
\%), likusi dalis - nekompensuojamus (34,2 \%). Didžiausia respondentų dalis receptinius vaistinius preparatus perka pagal 3 formos recepto blankus $(63,6 \%)$.

2. Farmacijos specialistai, išduodami receptinius vaistinius preparatus, suteikia minimalią informaciją apie vaistą. Vidutiniškai vieno vizito metu aptariama 1,62 vaisto vartojimo aspekto. Dažniausiai suteikiama informacija apie vaistą: kaip reikia vartoti, kada ir kaip ilgai vartoti išrašytą receptini vaistini preparatą. Daugeliu atvejụ informacija suteikiama žodžiu ir raštu, ir vidutiniškai skiriant 4,04 minutès laiko vienam pacientui.

\section{Literatūra}

1.Kamekis A. et al. Patients' intention to consume prescribed and non prescribed medicines: A study based on the theory of planned behaviour in selected European countries. Journal of Clinical Pharmacy and Therapeutics 2018; 43 (1): 26-35. https://doi.org/10.1111/jept.12601

2.Hämeen-Anttila K. et al. Multiple information sources and consequences of conflicting information about medicine use during pregnancy: a multinational Internet-based survey. Journal of Medical Internet Research 2014;16(2);e60. https:/www.ncbi. nlm.nih.gov/pmc/articles/PMC3961698/ [žiūrèta 2017 m. gruodžio $10 \mathrm{~d}$.]. https://doi.org/10.2196/jmir.2939

3. Kelling SE, Exploring accessibility of community pharmacy services. Innovations in Pharmacy 2015;(6/3):1-4.

4. Todd A, Copeland A, Husband A, Kasim A, \& Bambra C. Access all areas? An area level analysis of accessibility to general practice and community pharmacy services in England by urbanity and social deprivation. BMJ Open 2015;5(5). https://bmjopen. bmj.com/content/5/5/e007328?utm_source=TrendMD\&utm medium $=$ cpc\&utm_campaign=BMJOp_TrendMD-1. [žiūrèta 2017 m. gruodžio $\overline{10}$ d.]. https://doi.org/10.1136/bmjopen-2014-007328

5. LR Farmacijos ịstatymas. X-709. Valstybès žinios, 2006-07-18; 78-3056.

6. LR SAM ministro ịsakymas V-494. Dèl geros vaistinių praktikos nuostatų patvirtinimo. Valstybès žinios, 2007-06-21; 68-2690.

7. Tan EC, Stewart K, Elliott RA, George J. Pharmacist consultations in general practice clinics: the Pharmacists in Practice Study (PIPS). Research in Social and Administrative Pharmacy 2014;10(4):623-632.

https://doi.org/10.1016/j.sapharm.2013.08.005

8. Schommer JC, Wiederholt JB. The association of prescription status, patient age, patient gender, and patient question asking behavior with the content of pharmacist-patient communication. Pharm Res 1997;14(2):145-151. https://doi.org/10.1023/A:1012084207399

9. Koster ES. et al. Patient-provider interaction during medication encounters: A study in outpatient pharmacies in the Nether- 
lands. Patient Education and Counseling 2015; 98(7): 843-848. https://doi.org/10.1016/j.pec.2015.03.007

10. Daukšienè J. Visuomenès vaistinės pacientu gaunamos farmacinès ir sveikatinimo informacijos tyrimas ir vertinimas. Daktaro disertacija, 2010;121.

11. Boeni F, Arnet I, Hersberger KE. Adherence counseling during patient contacts in Swiss community pharmacies. Patient Preference and Adherence 2015;9:597-605. https://doi.org/10.2147/PPA.S76027

12. Chan FWK. et al. How much do elders with chronic conditions know about their medications? BMC Geriatrics 2013. https://bmcgeriatr.biomedcentral.com/articles/10.1186/1471-2318-13-59. [žiūrèta 2017 m. gruodžio 10 d.].

13. Creswell JW. Research design: Qualitative, quantitative, and mixed methods approaches. SAGE Publications 2009.

14. Kardelis K. Mokslinių tyrimų metodologija ir metodai, leidykla MECL, 2016.

15. Holden RJ. et al. Understanding older adults' medication decision making and behavior: A study on over the counter (OTC) anticholinergic medications. Research in Social and Administrative Pharmacy 2018. https://www.sciencedirect.com/science/ article/pii/S1551741117307738. [žiūrèta 2018 m. liepos 10 d.].

16. Puspitasari HP, Aslani P, Krass I. How do Australian metropolitan and rural pharmacists counsel consumers with prescriptions? Pharm World Sci 2009;31(3):394-405.

https://doi.org/10.1007/s11096-009-9289-9

17. Murad MS, Spiers JA, Guirguis LM. Expressing and negotiating face in community pharmacist-patient interactions. Research in Social and Administrative Pharmacy 2017; 13(6): 1110-1126. https://doi.org/10.1016/j.sapharm.2016.10.003

18. Svensberg K. Facilitators and barriers to pharmacists' patient communication: The Pharmacist Profession, the Regulatory Framework, and the Pharmacy Undergraduate Education 2017. https:/www.duo.uio.no/bitstream/handle/10852/57081/PhDSvensberg-DUO.pdf?sequence=1. [žiūrèta 2017 m. gruodžio 10 d.].
19. Mira JJ. et al. What older complex chronic patients need to know about their everyday medication for safe drug use. Expert Opinion on Drug Safety 2014; 13(6): 713-721.

https://doi.org/10.1517/14740338.2014.916272

\section{THE CONTENT OF COMMUNITY PHARMACY CON-} SULTATION FOR THE COMMUNITY PHARMACY PATIENTS WHO OBTAIN PRESCRIPTION MEDICATION: THE GENDER AND AGE GROUP INFLUENCE J.Daukšienė, L.Jonaitienė, E.Kizevičienè

Key words: pharmacist consultation, prescription medication. Summary

The primary purpose of patient medicines information is to assist the patient and health professional in achieving safe and effective use of medicines. This includes providing information that allows the patient to make an informed decision as to the appropriate selection and use of medicines. The pharmacy specialists play an important role in the process of ensuring the professional pharmaceutical service is provided. The aim of the study was to assess the information provided by pharmacist to the patients who purchase the prescription medication at Lithuanian community pharmacies.

The observation method was chosen. The special form with proposed indicators of encounter consultation was used. In total 4198 consultations were observed and 1331 prescription only consultation analysed. Community pharmacy patient receive personalized information on different medication use, illnesses and health topics at the pharmacy. Usually pharmacist show an initiative in providing medicine information to the patient. The amount of medicine information and length of the consultation depends on patient gender and age group.

Correspondence to: laimute.jonaitiene@go.kauko.lt

Gauta 2018-11-07 